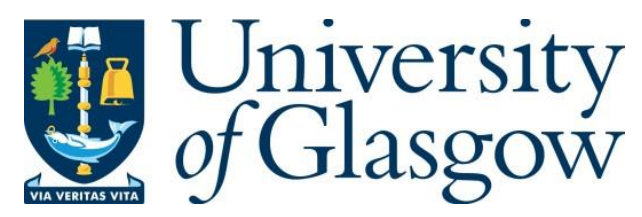

Young, G. (2019) The state and the origins of informal economic activity: insights from Kampala. Urban Forum, 30(4), pp. 407-423. (doi: 10.1007/s12132-019-09372-6)

There may be differences between this version and the published version. You are advised to consult the publisher's version if you wish to cite from it.

http://eprints.gla.ac.uk/209382/

Deposited on: 5 February 2020

Enlighten - Research publications by members of the University of Glasgow http://eprints.gla.ac.uk 


\title{
The State and the Origins of Informal Economic Activity: Insights from Kampala
}

\begin{abstract}
Understanding the root causes of informal economic activity is crucial for the effective governance of the informal sphere. Precisely what these root causes are, however, is subject to significant debate. This article contributes to these debates by arguing that the state is central to the origin and evolution of informality. Stressing the importance of understanding informality through a historically rooted political economy approach, it analyzes the modern history of informal vending in Kampala, Uganda, and identifies six ways in which the state has fundamentally shaped informal economic activity in the city: colonial planning; a history of poor governance and instability; economic liberalization; geographic development trends; an ineffective taxation regime; and the self-interest of state officials. An appropriate understanding of the centrality of the state in the informal economy highlights the necessity of designing effective institutions, policies and interventions that prioritize the needs of the urban poor.
\end{abstract}

Keywords: Informal Economy; Informal Vending; State Power; Governance; Kampala; Uganda

Informal economic activity is a global phenomenon. In cities across Africa, Asia and Latin America, the trade of otherwise legal goods and services outside of the regulatory and taxation structures of the state is subject to various forms of co-operation, co-option, repression and neglect by governments that view it as a nuisance, a source of marginal survivalist activities, an obstacle to development or a potential driver of economic growth. A more coherent and proactive approach to informal economic governance is needed, and this itself must be based on a full understanding of the how and why informal economies emerge and evolve over time.

The underlying causes of informal economic activity have long been a subject of intense scholarly and policy debate. While some hold that informality is a by-product of underdevelopment that will be eradicated with economic growth, others contend that it is a form of market exploitation and still more claim that is the result of a rational response to ineffective economic governance and unpopular laws and regulations. ${ }^{1}$ This article contributes to these debates by arguing that the origin and evolution of informality can only be understood through a historically rooted political economy approach that places the state at the centre of analysis. Adopting such an approach in its exploration of informal vending in Kampala, Uganda, it highlights six ways in which the state has played a central role in creating, sustaining or otherwise shaping informality: through the history of colonial planning in the city; through Uganda's post-

\footnotetext{
${ }^{1}$ Each of these views is explored in the subsequent section of this paper.
} 
independence history of poor governance and instability; through the country's extensive economic liberalization; through internal geographic trends of development that have fuelled urban growth in Kampala; through the country's tax system; and through the self-interest of state officials who gain political and/or economic benefits from the existence of the informal sphere.

The analysis of the relationship between the state and the informal economy presented here is based on a combination of primary and secondary research methods. Over 130 informal vendors, formal sector business people, state officials and civil society officials were interviewed in Kampala in 2015 as part of a broad study of the politics of informal vending in the city. Extensive analysis of policy reports, newspaper articles and relevant constitutional and legislative documents was also undertaken to expand on crucial points identified during fieldwork and construct a complete account of the role of the state in the city's informal sphere.

The remainder of this article is divided into three sections. The first explores current literature on the causes of informal economic activity and details the primary features of dualist, structuralist and neoliberal accounts. The second then turns its attention to the Kampala, Uganda, to examine the fundamental role that the state has played in informal economic activity in the city. The significance of colonial planning, governance and instability, economic liberalization, the geography of development, taxation and the self-interest of state officials are all explored. Conclusions are offered in the final section, where the implications that this state-centric approach has for informal economic governance are discussed.

Three Perspectives on the Causes of Informal Economic Activity

Common explanations of the causes of informal economic activity can be divided into three categories: dualist accounts that cast informality as a feature of underdevelopment; structuralist accounts that frame informality as a form of exploitation; and neoliberal accounts that view informality as the aggregate result of the rational choices of individual entrepreneurs. ${ }^{2}$

\section{Dualism}

Early approaches to informal economic activity view the informal sphere as largely unconnected to its formal counterpart and comprised of individuals undertaking marginal activities

\footnotetext{
${ }^{2}$ For various treatments of the literature on informal economic activity, see: Carr and Chen (2001); Chen (2012); Gërxhani (2004); Habib-Mintz (2009); Losby et al. (2002); Rakowski (1994); and Yusuff (2011).
} 
as a form of livelihood support (Hart 1973; and ILO 1972). These are defined by the common view, inherent in early forms of Marxism, neoclassical economics and modernization theory, that capitalist development would necessarily lead to the dramatic transformation of pre-capitalist political economies and involve the widespread absorption of labour. From this perspective, the informal sphere exists as a result of inadequate demand for the high supply of labour that underdevelopment entails; the growth of the formal sector, it was assumed, would increase opportunities for formal employment, thereby reducing the disconnect between the supply of and demand for labour that resulted in excess capacity. ${ }^{3}$

\section{Structuralism}

Structuralist accounts view the informal sphere as inherently subordinate to its formal counterpart (Moser 1978; Portes et al. eds. 1989; and Portes and Schauffler 1993). For structuralists, the formal and informal spheres are connected through a wide range of complex mechanisms and relationships in a way that allows the former to function through the exploitation of the latter. According to this understanding, informality plays a key role in the capitalist system by supplying low-cost goods and services for formal firms, facilitating the maximization of profits through the minimization of expenditures on labour, production and distribution. Formal workers also benefit from the existence of the informal sphere as it allows them to survive on otherwise inadequate wages, while wealthier participants in the informal economy are able to sustain or improve their socioeconomic position by taking advantage of less expensive goods and services. From this perspective, informality is therefore produced and sustained through the division of labour and forms of production, distribution and accumulation that define capitalism and exist both domestically and internationally, and thus constitutes a form of unequal market integration rather than exclusion.

\section{Neoliberalism}

Neoliberal interpretations of informality instead view informal economic activity as the result of rational economic behaviour. The work of Hernando de Soto (1989) is particularly important here. In his analysis of informal economic activity in Peru, de Soto portrays the informal

\footnotetext{
${ }^{3}$ Habib-Mintz (2009). For the similarities between Marxist and more orthodox approaches to the role of the informal sphere in the political economy of development, see Portes and Sassen-Koob (1987).
} 
sphere as a site of market creativity and dynamism that is populated by a diverse array of smallscale entrepreneurs. In doing so, he employs the emphasis that neoclassical economic analysis places on rational actors to argue that informal actors weigh the respective costs and benefits that informality and formality each entail, and choose the former, despite its undesirability, due to the burdens that governments place on the latter. For de Soto, therefore, engaging in informal economic activity is a form of contesting the state, with the conscious evasion of official legal and regulatory structures serving as a popular challenge to the state's poorly managed economic dominance.

De Soto does not, however, view informal economic activity as entirely beneficial. Instead, he argues, it can have a variety of negative effects: reduced levels of productivity and investment, higher prices for services, minimal technological development and difficulties collecting tax revenues and constructing macroeconomic policy. De Soto therefore argues that the state must act to formalize the informal sphere, and asserts that it is best able to do so by reducing the costs of formality and reforming the legal system to provide protections for property rights, contracts and extracontractual liabilities. De Soto's work is tied to the broader idea that underdevelopment is caused by overly restrictive, burdensome or distortionary state policies and can be 'solved' through market reforms. The idea that markets are a solution to rather than a cause of informality has inspired a vast amount of literature advocating lower taxes, fewer regulations and less bureaucracy as the best means of reducing the costs of entering the formal sphere and harnessing the developmental potential of informal entrepreneurs, with the neoliberal interpretation of informality coming to dominate mainstream scholarship (Albrecht et al. 2009; Bromley 1990; Djankov et al. 2010; Ihrig and Moe 2004; Loayza 1996; Maloney 2004; Schneider and Enste 2000; and Sparks and Barnett 2010), major international institutions, most notably the World Bank (Perry et al. 2007 and popular accounts (Neuwirth 2011). De Soto's work therefore not only provides an important understanding of how informal actors contest the state, but also informs orthodox approaches to how the state should, in turn, act to reduce informality. It remains a central reference point for all contemporary analysis of informal economic activity. 
The State and the Roots of Informality in Kampala

Dualist, structuralist and neoliberal interpretations dominate standard explanations of the origins and evolution of informal economic activity. What each lacks, however, is a comprehensive account of the centrality of the state.

The state plays a crucial role in producing and perpetuating informal economic activity both in Kampala and in Uganda more generally. Six ways in which it has done and continues to do so are explored here: through colonial planning; through a history of poor governance and instability; through economic liberalization; through geographic development trends; through tax policy; and through the self-interest of state officials.

\section{Colonial Planning}

Kampala's physical and economic landscape has been profoundly influenced by its colonial heritage. Kampala first became a township under the British colonial administration in 1902, and with gradual expansion, came to cover what are now the areas of Nakasero, Kololo and Old Kampala in Kampala Central Division by the late colonial period. Colonial Kampala was adjacent to, but administratively separate from, the indigenous city of Mengo to the immediate south and west, which served as the capital of the Buganda Kingdom, the traditional home of the Baganda people, Uganda's largest ethnic group. While Kampala was administered by the British colonial authorities and had a population that was almost exclusively made up of European and Asian (primarily Indian) settlers and their descendants, Mengo remained an indigenous settlement that was outside of the boundaries of Kampala and governed by the Buganda Kingdom. The British colonial administration adopted major urban plans for Kampala in 1912, 1919, 1930 and 1951, all of which had the same technocratic objective of designing an orderly colonial urban environment that was centred on the segregation of European, Asian and African populations for racial and (racialized) sanitary purposes. These plans still underpin the fundamental layout of the present city; the major markets in Kampala, for example, are concentrated in what were formerly the designated European and Asian trading areas around Kampala Road, particularly to the south and west before the boundary with Mengo (Omolo-Okalebo et al. 2010). Kampala was finally expanded to incorporate Mengo, along with the other indigenous towns of Nakawa and Kawempe, in 1968, six years after the end of colonial rule in Uganda (Makara 2009, 235). 
Colonial planning in Kampala had a significant impact on the evolution of informal economic activity in the city. The early separation of Kampala and Mengo effectively created a dual city in which the African population of Mengo was excluded from the colonial city centre and economy; this division, in many ways, continues to exist. Not only do large segments of Kampala's population remain outside of the city's formal economy, but colonial understandings of urban order serve as an important precursor to the later aspirations of urban management and development that have come to play such a crucial role in the city's politics. The view that informal vending is chaotic and that it violates the city's aesthetic and sanitary standards strongly reflects colonial views of well-ordered urban space. What was formerly a system of spatial and economic exclusion along racial lines has transformed into a system of exclusion along socioeconomic lines. ${ }^{4}$ Informal vendors, like the indigenous residents of Mengo before them, belong to a segment of the population that has little or no access to formal economic life in the city, and they remain unwelcome in the city centre due to many of the same understandings of urban order that came to prominence in the colonial period.

\section{Governance and Instability}

Poor governance, instability and conflict have been defining features of Uganda's postcolonial history. All of these can stimulate informal economic activity by precipitating formal economic collapse. Such problems were particularly acute during the presidency of Idi Amin (1971-1979), allowing new forms of accumulation to arise (Kasfir 1983). The expulsion of the country's Asian population and the seizure of their assets in 1972, the increased use of the state for patronage purposes and the introduction of controls all facilitated economic crisis and the rise of informality (Bigsten and Kayizzi-Mugerwa 2001, 17-18). Indexed to 100 in 1960, Uganda's per capita GDP fell from 106 in 1971 to 66 in 1979, while domestic investments decreased from 15\% to $6 \%$ of GDP, exports declined from $19 \%$ to $3 \%$ of GDP, inflation increased from $4 \%$ to $216 \%$ and external debt grew from 172.4 million USD to 590.2 million USD (ibid, 18). Conflict and instability continued after Amin was overthrown, with the country's next two leaders, Yusuf Lule and Godfrey Binaisa, removed from office in a period of 13 months, Milton Obote returning to the presidency following a disputed election and, most significantly, the civil war that ultimately brought the National Resistance Movement (NRM) and Yoweri Museveni to power. By the end

\footnotetext{
${ }^{4}$ For a critique of the importance of colonial heritage in the politics of vending, see Morange (2015).
} 
of the war in 1986, Uganda's economy was still in far worse shape than it had been in 1971: indexed GDP had fallen to 60, domestic investments were at $8 \%$, exports were at $9 \%$, inflation was at $96 \%$ and external debt was at 1.422 billion USD (ibid, 20).

The sustained period of economic crisis that the country experienced under Amin led to a proliferation of black market activities, known in Uganda as magendo. Scarcities produced by the widespread collapse of the formal economy, fuelled by unrealistically low state-imposed price controls and an overvalued official exchange rate, resulted in new forms of distribution surrounding the sale of high-demand goods and services at significantly inflated profit margins. Magendo proved to be highly lucrative for many involved in it, and evolved to the point where it developed its own internal class structure that was characterized by an elite group of between five and five hundred wealthy mafuta mingi, about 2,500 mid-level magendoists and, at the bottom, a group of bayaye, which made up 7\% of the country's population and was comprised of labourers, drivers, enforcers and, importantly, street vendors. The extent and cohesiveness of these hierarchies is uncertain, but they changed dramatically when the political conditions that produced magendo largely disappeared with the fall of the Amin regime and a period of further political and economic upheaval ensued (Kasfir 1983).

The NRM's victory did not end conflict in Uganda. It instead made it more regionalized. Tripp (2010, 149-179) identifies twelve major armed groups that have engaged in conflict with the government since 1986, including one in the Central region, two in the Western region, two in the Eastern region (where cattle raiding has also been a considerable problem) and seven in the Northern region, the most notable of which is the Lord's Resistance Army (LRA). The state has played a significant role in perpetuating conflict with the LRA by severely neglecting the region and carrying out major abuses on its population, pursuing contradictory resolutions to the conflict and even allowing the war to continue for economic or political reasons. This reflects a broader marginalization of Northern Uganda by the NRM, which has its roots in the southern, and particularly western, part of the country. ${ }^{5}$ Such conflict can prevent formal sector development and cause significant population displacement, contributing to the growth of informality.

\footnotetext{
${ }^{5}$ Also see Carbone (2008, 63-76).
} 


\section{Economic Liberalization}

Uganda has adopted extensive reforms to liberalize its economy. Initiated in two stages, first by Milton Obote in 1981 and subsequently by the NRM in 1987, in co-operation with the World Bank and the International Monetary Fund (IMF), these entailed the introduction of a standard set of market-oriented policies that were aimed at promoting growth, stabilization and a sustainable balance of payments (Bigsten and Kayizzi-Mugerwa 2001, 19-23). Due to the country's subsequent performance, these reforms have been viewed as a major success. Annual growth averaged around 7\% in the 1990s and 2000s (The World Bank 2015b, 6), exceeding the Sub-Saharan African average in both decades $\left(2 \%{ }^{6}\right.$ and $5.7 \%,{ }^{7}$ respectively). Inflation decreased, trade and foreign direct investment (FDI) grew and services and industry have increased significantly, at the expense of agriculture, as a percentage of GDP (The World Bank 2018c). Livelihoods in the country have also undergone a major transformation, with the number of Ugandans living in poverty falling from 55.7\% in 1992/93 (Okidi et al. 2005, 6) to $19.7 \%$ in 2012/13 before rising slightly to 21.4\% in 2016/17 (Ugandan Bureau of Statistics 2018, 90).

This performance, however, has important caveats. Early growth, while high, was significantly aided by the end of conflict, higher coffee prices and international aid, and nominal GDP per capita only returned to its 1971 level in 1996 (The World Bank 2007, 4), while in real terms, it still lagged its 1960 level in 1999 (Bigsten and Kayizzi-Mugerwa 2001, 16 and 22). The

impact of reforms is therefore difficult to measure. Growth has also been uneven; poverty would have declined by a further 20\% between 1992/93 and 2009/10 if inequality levels had remained constant (The World Bank 2012, 9). Urban inequality has risen, from a Gini coefficient of 0.363 in $2005 / 06$ to 0.410 in 2012/13, even while rural inequality has dropped (ibid, 33). Early performance levels have also proven difficult to sustain, with growth slowing from 2012, and inflation remains erratic (The World Bank 2018c). The country's privatization process itself was defined by pervasive cronyism and corruption (Tangri and Mwenda 2001), while the support provided by foreign donors for liberalization reforms has fuelled patronage by providing the government with extensive resources that can be distributed with little accountability (Mwenda and Tangri 2005).

\footnotetext{
${ }^{6}$ The World Bank $(2015 b, 6)$.

7 The World Bank (2015a, 106).
} 
What is particularly relevant here is how economic liberalization has impacted informality. While a lack of economic data on the historical evolution of Uganda's informal sphere makes it difficult to empirically assess the effect of liberalization, three primary mechanisms that define this causal relationship more generally can be identified. The first of these is privatization and the reduction of public employment. Throughout the 1990s, 62 of the country's 156 public enterprises were subjected to some form of privatization and a further 31 were liquidated, ${ }^{8}$ while the number of civil servants employed by the state fell by about 50\%, from 320,000 to 160,000, between 1992 and 1999. ${ }^{9}$ Efforts to reduce state spending and introduce market pressures can have an immediate negative impact on formal employment by causing large numbers of people employed in the public sector and/or by parastatals to lose their jobs. Without an equivalent increase in formal employment in the private sector, many of these people will be forced into the informal sphere to secure their livelihoods. Second, free trade can increase imports that harm domestic producers, and demand for exports (where it exists) may fail to produce employment if it is met through productivity growth (Lee and Vivarelli 2006). Such an occurrence is contrary to key components of neoclassical trade theory-notably the Heckscher-Ohlin model, which states that developing countries will take advantage of their abundant supply of cheap labour to export labour-intensive goods while importing capital-intensive goods, and the Stolper-Samuelson theorem, which states that a rise in prices for labour goods will result in increased labour demand, raising wages - but is nevertheless empirically observable (Verick 2006; and Lee and Vivarelli 2006). The fewer sectors in which a country has a comparative advantage, the larger the rise in informality resulting from liberalization will be (Ghosh and Paul 2008). Finally, FDI can also harm formal employment by driving out domestic firms, by introducing new technologies and through mergers and acquisitions (Lee and Vivarelli 2006).

Proponents of liberalization maintain that the labour market effects of reforms represent short-term shocks rather than long-term consequences. ${ }^{10}$ Liberalization, however, has certainly not yet led to adequate formal job creation in Uganda. Growth in output in non-agricultural sectors has not been matched by a proportional growth in demand for labour, with over $70 \%$ of Ugandans still

\footnotetext{
${ }^{8}$ Collier and Reinikka (2001, 37). Total number of public enterprises taken from Carbone (2008), 53. For this process, see Tangri and Mwenda (2001).

${ }^{9}$ Collier and Reinikka (2001), 27. Carbone $(2008,54)$ claims this decline took place in "less than five years".

${ }^{10}$ For the argument that liberalization can have negative short-term effects followed by positive long-term effects on the labour market, see Bacchetta et al. (2009).
} 
engaged in agriculture in 2013 despite its diminishing share of GDP (The World Bank 2013, 2224). The sectors of the economy that have experienced the most growth are not labour intensive, while sectors that do require more labour have seen little productivity growth. This means that an asymmetry exists between economic growth and new employment, with high growth sectors not adequately contributing to formal employment and high employment sectors not adequately contributing to growth. Employment patterns have also changed across firms. Total employment actually declined in firms with more than five employees outside of trade, manufacturing and hotels and restaurants during the 1990s (The World Bank 2007, 36-40), and the average number of employees at larger firms fell in the 2000s (The World Bank 2013, 36). Across all sectors and firms, the total number of jobs that have been created falls significantly short of the needs of the country's labour market. According to a 2013 World Bank report, Uganda has the fastest growing labour force in the world, outpacing job creation to the point that only about $20 \%$ of young labour market entrants are able to secure wage employment (ibid, 28 and 35).

The informal sphere acts as a cushion to absorb this excess labour capacity, making it a key feature of Uganda's structural transformation. Indeed, as a study by the World Bank points out, with high productivity growth and insufficient employment opportunities, the informal sphere allows the country's transition to be more broad-based, contributing to faster growth, less inequality and lower poverty (Fox and Pimhidzai 2011). Without it, a significantly larger share of the country's population would be stuck in low-productivity agriculture, waiting to be absorbed into the formal labour market to participate in the country's narrow growth. Following structuralist accounts, the informal sphere also buttresses the formal economy by providing it with low-cost inputs and cheap labour, providing goods and services to formal workers with low wages and acting as a source of demand for formal sector goods. Economic liberalization therefore not only helps produce informality, but is dependent upon it for its success.

\section{The Geography of Development}

Development varies significantly across Uganda, with notable differences both between and within regions. In 2016/17, $12.7 \%$ of the population in the Central region lived in poverty, compared to $11.4 \%$ in the Western region, $32.5 \%$ in the Northern region and $35.7 \%$ in the Eastern region (Uganda Bureau of Statistics 2018, 90). While the number of people living in poverty in the Central region fell by more than half between 1992/93 and 2009/10, it rose by about 300,000 
in the Northern region over the same period (The World Bank 2012, 3). Within regions, the main differences exist between rural and urban areas. In 2016/17, the urban poverty rate stood at just 9.6\%, and only 2.6\% in Kampala (Uganda Bureau of Statistics 2018, 90). Access to basic services in Kampala exceeds both rural areas and other urban centres (The World Bank 2015b, 47). Employment opportunities are also concentrated in urban areas, which experienced $65 \%$ of Uganda's job creation between 2001 and 2010, and in Kampala and the surrounding area in particular (ibid, 29). Wages for these jobs are in excess of those in rural areas. In total, urban areas account for $70 \%$ of non-agricultural GDP (ibid, 41).

These differences make urban centres attractive alternatives to the countryside, fuelling urban growth. Although Uganda remains a largely rural country, with only $23.8 \%$ of its population living in cities, it is experiencing the fastest rate of urbanization in the world at an estimated 5.7\% per year between 2015 and 2020 (United Nations 2018). Kampala is by far Uganda's largest urban agglomeration, containing $6.4 \%$ of the country's population and $29.1 \%$ of its urban inhabitants (ibid). ${ }^{11}$ Kampala's population has increased from just 755,000 in 1990 to 2,986,000 in 2015 (ibid), and the city experienced an average annual growth rate of $4.91 \%$ per year between 2010 and $2015 .^{12}$ These growth trends are likely to continue on their upward trajectory, with the UN estimating that Kampala, with an average annual growth rate of $5.11 \%$, will be the second fastest growing urban agglomeration in the world between 2025 and 2030 behind Bujumbura, Burundi (5.3\%), and the fourth fastest growing urban agglomeration between 2030 and 2035 behind Bujumbura (5.02\%) and Zinder (5.38\%) and Niamey (5.37\%), Niger (ibid).

This urban growth contributes to the prevalence of informal economic activity. This is primarily because it is not accompanied by adequate formal job creation. In fact, the portion of the country's jobs located in urban areas fell from 75\% in 2001 to 70\% in 2010 (The World Bank 2015 b , 42). In 2015, 85.8\% of the working population in Kampala were in informal employment; for all urban areas in Uganda, the figure was 86.2\% (Uganda Bureau of Statistics 2017, 169). The state is heavily implicated in this process of urban growth and informality. Primarily, as discussed above, it has failed to prioritize formal job creation, forcing the informal sphere to absorb the impact of the transition from agricultural to non-agricultural work. It has also facilitated this

\footnotetext{
${ }^{11}$ The UN elsewhere puts the former at $4.8 \%$ and the latter at 29.9\% (2015, 467 and 433), while the World Bank claims the latter is $35 \%$ (2015b, 33).

${ }^{12}$ Figures for the Kampala urban agglomeration.
} 
process by failing to address, or, through its development plans, exacerbating, rural/urban differences. As a Member of Parliament from Kampala pointed out, the government has allowed Kampala to become the country's unrivalled economic and political centre where jobs and services are concentrated, but uses its coercive power against the informal street vendors who come to the city in search of better livelihoods. ${ }^{13}$ Such efforts have caused many vendors to leave Kampala and relocate either to the city's periphery or back to the countryside. They have not yet, however, succeeded in eradicating street vending.

\section{Taxation}

The government of Uganda is currently undertaking a concerted effort to formalize the country's informal sphere by bringing it within the national tax structure. The primary rationale for such efforts is to enhance revenue collection by broadening the tax base, but proponents of similar plans elsewhere also claim that taxing the informal sphere can have the more general benefits of promoting economic growth and good governance (Joshi et al 2012; and Tax Justice Network 2012). Uganda's need to boost domestic revenue collection is clear: at $13.8 \%$ in 2016/17, the share of its GDP that the government takes in as revenue is extremely low, falling considerably short of both the regional average and total expenditures (The World Bank 2018b, 21). Despite its current if inconsistent upward trend (ibid, 21-22), this figure has increased only marginally since rising from just 7\% in 1991 to around 12\% in 1997 (Fjeldstad 2005, 2). Efforts to tax the formal sphere were intensified with the introduction of Uganda's 2015/16 National Budget, which, amongst other changes, made Tax Identification Numbers (TINs) mandatory and increased the threshold for presumptive tax from 50 million Ugandan shillings (UGX) ${ }^{14}$ to 150 million UGX. The Uganda Revenue Authority (URA) expected the changes introduced with the budget to raise revenue mobilization to $14 \%$ of GDP, a figure that is still comparatively low. ${ }^{15}$ By June 2015 , one month before these measures came into effect, 21,047 people, including 20,368 in Kampala, had already been registered through the Taxpayer Registration Expansion Program (TREP), bringing in 800 million UGX (Ladu 2015a), while the URA had identified 100,000 informal businesses to target for tax payments (Nantaba 2015).

\footnotetext{
${ }^{13}$ Interview, Member of Parliament, Parliament of Uganda, 27 July 2015.

${ }^{14}$ The value of the Ugandan shilling fluctuated between approximately 3619 and 3884 UGX to USD throughout 2018.

${ }^{15}$ Figure taken from Ladu (2015a). Also see; Akol (2015); Busuulwa (2015); Uganda National Chamber of Commerce and Industry (2015); and Tentena (2015).
} 
Of course, neoliberal analyses of informal economic activity point to taxation as a major source of informality. The logic of this argument rests on the comparative costs and benefits of formality and informality: as taxation raises the costs of formality, it offsets the benefits of formalization, changing the calculus that enterprises face. There is evidence that dissatisfaction with what is seen as excessive taxation is widespread. A spokesperson for the Kampala City Traders Association (KACITA) criticized the number of taxes formal businesses are subject to, including corporate income tax (30\%), value-added tax (18\%), withholding taxes (6\%) and import duties $(25 \%) .{ }^{16}$ One small shop owner complained of having to pay 200,000 UGX in taxes on a 400,000 UGX income, with a further 150,000 UGX going to rent. ${ }^{17}$ Another was similarly unhappy about having to pay 2 million UGX in combined taxes and rent on an income of 2.5 million UGX. ${ }^{18}$ A third complained that taxes, combined with various fees and transportation costs, can raise the cost of importing a container of goods in excess of the value of the goods themselves. ${ }^{19}$ Operating in the informal sphere does not mean that one is free from the effects of these taxes. Informal vendors may pay some taxes themselves, which can force them to raise their prices, diminishing their competitiveness and making their goods unaffordable to many of their customers, particularly those who also engage in informal activities. ${ }^{20}$ Even a vendor who does not personally pay taxes can still be affected by higher prices when a supplier is taxed. ${ }^{21}$

Concerns about taxes are tied to broader complaints about the costs that Uganda's current regulatory structure imposes on formal businesses. The World Bank's Doing Business project ranks Uganda's regulatory environment at 127th in the world according to a set of criteria derived from the principles of economic liberalism, noting that it takes 24 days and $33.6 \%$ of per capita income to start a business and that such tasks as acquiring construction permits, getting electricity and property registration can be both lengthy and costly. ${ }^{22}$ The country's Business Licensing Reform Committee "conservatively" estimates the annual costs of adhering to all requirements for a business license to be 725.73 billion UGX, equal to $3.49 \%$ of GDP (Business Licensing Reform Committee 2012). Concerns about these costs were expressed in interviews with both KACITA ${ }^{23}$

\footnotetext{
${ }^{16}$ Interview, KACITA representative, 11 July 2015.

${ }^{17}$ Interview I, shop vendor, 17 August 2015.

${ }^{18}$ Interview II, shop vendor, 17 August 2015.

${ }^{19}$ Group interview, shop vendors, 8 July 2015.

${ }^{20}$ Ibid.

${ }^{21}$ Interview I, Owino Market vendor, 9 July 2015.

22 The World Bank (2018a). Figures for starting a business taken from page 6 .

${ }^{23}$ Interview, KACITA representative, 11 July 2015.
} 
and the Private Sector Foundation Uganda (PSFU). ${ }^{24}$ It is possible that such costs serve as a disincentive for formalization.

The relationship between taxation and informality, however, is not as simple as the neoliberal argument suggests. Uganda's taxation system likely contributes to the prevalence of informal economic activity in the country, but the reason it does so is not simply because rates are too high. Three other factors are commonly ignored: that poor service provision by the Ugandan government means that there are few incentives to pay; similarly, that widespread corruption means that many believe money paid in taxes will not be spent for the public good; and that rates are not necessarily too high, suggesting that all business taxes need to be reduced, but that they are too regressive, with the government neglecting to implement more progressive alternatives that would target different sources of revenue.

A significant dissatisfaction with the poor quality or lack of services provided by the government was expressed by a number of interview respondents. This was explicitly linked to views on taxation, and the argument that people would be much more willing to pay their taxes if they felt their money would be spent on services that had an identifiable personal or social benefit. As one respondent claimed, "[p] eople would be much happier to pay if they saw where their money was going", stating: "I would be much happier to pay tax if I went to public schools and they had facilities, if I went to hospitals and they had medicine.... Why should I give you my money for garbage collection when I'm going to have to pay someone to collect my garbage? If you want me to pay you, then get somebody to collect my garbage." 25 This is particularly pronounced for informal actors who receive little from the government either as economic agents or members of the urban poor. As one street vendor put it, the government "milk[s] the cow without giving it grass", demanding taxes from informal vendors while providing them with little or no support. ${ }^{26}$ The URA's internal research recognizes that popular perceptions of the government have a major impact on tax compliance, with views of service provision the most important factor in this regard. The problem from the perspective of the URA, however, is that it is specifically tasked with the collection of revenue, and detached from the broader political processes that form policy and

\footnotetext{
${ }^{24}$ Interview, PSFU representative, 20 July 2015.

${ }^{25}$ Interview, KACITA representative, 11 July 2015.

${ }^{26}$ Group interview, street vendors, 8 July 2015.
} 
influence compliance. ${ }^{27}$ If paying taxes involves a calculation of costs and benefits, the government is not providing adequate inducements for formalization.

Paired with the widespread dissatisfaction with service provision is the popular perception that money paid to the state in taxes will merely be stolen by corrupt officials (Nkonge 2013). A spokesperson for KACITA questioned why a person should have to pay their taxes "to send the money to government for personal use rather than public good". ${ }^{28}$ Corruption is a significant problem in Uganda, with the country ranked $151^{\text {st }}$ of 180 in Transparency International's Corruption Perceptions Index (2018). Corruption is pervasive throughout major government institutions, including the URA, where a 2005 study found declining real wages, few consequences for poor performance and widespread political interference and patronage (Fjeldstad 2005). The fact that officials may accept or demand bribes in exchange for tax relief further undermines revenue collection. One study finds that, for a firm, on average, a one percent increase in bribe payments per employee results in a seven percent reduction in taxes per employee (Gauthier and Goyette 2014).

There are also significant problems surrounding the progressivity of Uganda's tax system. Even though the country's corporate tax rate is set at $30 \%$, and presumptive taxes are approximately $1.5 \%$ to $3 \%$ (and $0 \%$ under 150 million UGX) (Uganda National Chamber of Commerce and Industry 2015), a 2012 World Bank report noted that non-agricultural household enterprises, many of which are informal, have an effective tax rate of $52 \%$ due to the costs of various fee payments. This means that taxes on businesses are, in effect, regressive, and consume a larger share of income for smaller enterprises than larger firms. While the Ugandan government seeks to expand the country's tax system within the informal sphere, it ignores other major sources of revenue. Uganda is one of the few countries in the world where owner-occupied residential properties are not taxed (The World Bank 2015b, 57), despite the fact that property taxes have minimal impact on economic activity and are generally proportionate to a taxpayer's wealth. Foreign investors also receive generous exemptions. One 2012 study lists three different tax incentives offered to all investors, four to exporting companies, two special corporate and withholding tax exemptions, seven incentives for businesses operating in designated free trade areas and a variety of sector-specific incentives (Tax Justice Network - Africa and ActionAid

\footnotetext{
${ }^{27}$ Group interview, URA, 11 August 2015.

${ }^{28}$ Interview, KACITA representative, 11 July 2015.
} 
International 2012). The African Development Bank (AfDB) estimated the total revenue lost to these incentives in 2009/10 to be at least 690 billion UGX, equivalent to two percent of GDP (ibid, 1). This figure rose to about 1.5 trillion UGX in 2013/14, a year when total revenues were approximately 8 trillion UGX (Ladu 2015b). As a result, more of the tax burden is falling on (generally) poorer informal actors than wealthier international investors. Such exemptions are not only damaging to revenue collection, but also make little economic sense. One survey found that over $92 \%$ of investors benefiting from tax incentives in Uganda would have made the same investments even if no incentives were on offer (Awasthi 2012). Indeed, many of the foreign donors that Uganda depends upon for a significant portion of its national budget have expressed dissatisfaction with the impact of the country's tax incentives on domestic revenue mobilization (Mbanga 2003; and Mweisgwa 2012).

Uganda's tax system therefore contributes to the prevalence of informality in the country. It does so, however, not because rates are too high, but because revenues are disconnected from service provision, corruption undermines compliance and the entire regime is regressive and poorly designed for revenue maximization. Failures in the country's tax system therefore reflect broader failures in governance. The informal economy is currently being targeted while these remain unaddressed.

\section{The Self-Interest of State Officials}

State corruption, as discussed above, can promote informality by reducing tax compliance. More generally, it can also reduce economic growth (Gyimah-Brempong 2002; and Mo 2001), and while growth has not led to adequate formal employment creation in Uganda, lower growth due to corruption is not conducive to formal sector expansion. At a lower level, corruption amongst state officials who are charged with carrying out efforts to reduce informality can result in poor enforcement. This, again, can be true for tax administrators, or for those charged with implementing Kampala's ban on street vending. Indeed, the problem that street vendors in particular face is not merely that the state is excessively regulatory, but that it is also predatory, with state agents taking advantage of vendors' vulnerability. ${ }^{29}$

Besides merely being corrupt, state officials may also have direct economic interests in particular informal sectors. Kampala's ubiquitous matatus are commonly owned by politicians,

\footnotetext{
${ }^{29}$ A similar point in made in Anjaria (2006).
} 
particularly in the NRM, who are able to undermine attempts to regulate the industry, and have experienced a level of success in resisting the attention of the state that stands in notable contrast to, as one Member of Parliament highlighted, the experiences of street vendors. ${ }^{30}$ Less widely known is the fact that many state officials allegedly own structures, often several, in major markets throughout Kampala, something that is likely facilitated by plans to sell market space to investors to finance redevelopment projects. These economic interests offer little incentive to alter the status quo surrounding informality, or, in the case of markets, provide a strong incentive to support development plans that will lead to personal financial gain.

The interest that state officials have in the informal sphere is not merely financial. Politicians can rely on informal actors for electoral support, and in exchange for providing this support, informal actors are able to enjoy a certain degree of political protection. ${ }^{31}$ Thus, the desire for expanding or reinforcing political power can clash with other regulatory objectives surrounding urban management and development, allowing informality to thrive despite official formalization or regulation efforts. Such a system of exchange, however, is dependent on particular political circumstances; when these circumstances change, it can similarly be in the interests of state officials to repress informal actors or seek to impose forms of urban management and development that are exclusionary. This is precisely what happened in Kampala as the recent de-democratization of local politics resulted in the repression of street vending (Young 2018 and 2017).

\section{Conclusions}

Informal vending in Uganda is inseparably tied to the state. Through past colonial planning, a history of poor governance and instability, economic liberalization, geographic development trends, its taxation regime and the self-interest of state officials, the state has played a major role in the emergence and growth of the country's informal sphere. In the absence of adequate formal employment opportunities and formalization incentives, the informal sphere has become a key livelihood source for a significant portion of the country's population, underlying the supposed success of Uganda's economic transformation. Despite the crucial developmental role that it plays, however, the informal sphere is nevertheless targeted by the state for failing to adhere to a

\footnotetext{
${ }^{30}$ Interview, Member of Parliament, Parliament of Uganda, 27 July 2015. The ownership of matatus is also discussed in Goodfellow (2010, 17-18).

${ }^{31}$ This phenomenon has been observed elsewhere, perhaps most notably in Latin America. See, for example: Cross (1998); and Holland (2016 and 2017).
} 
particular notion of development, meaning that the state both creates conditions in which informal economic activity becomes a crucial form of livelihood support while also (inconsistently) punishing those who engage in it (Young 2018 and 2017).

Recognizing the centrality of the state in the origin and evolution of informality has important implications for informal economic governance. Primarily, it further underlines the importance of designing effective institutions, development policies and interventions that can promote inclusive governance. If the existence of informal economic activity is largely the result of the failures of the state, then addressing these failures is of paramount importance for governments that wish to promote formalization. Addressing the urban divisions creating by colonial planning, minimizing predatory governance and conflict, easing the dislocations caused by economic liberalization, reducing geographic inequalities in development, designing an inclusive tax system and reformulating incentive structures that encourage state officials to pursue private over public goods are all crucial for effective informal economic governance. There are, of course, major barriers to each of these objectives; indeed, they are what make informality so intractable and lead to the widespread failure of informal economic governance. If states truly wish to implement effective informal sector governance, however, then their own role in causing and perpetuating informality can no longer be ignored. 


\section{Bibliography}

Akol, Doris. 2015. "Informal Sector is Threat to Tax Revenue Collection.” The Observer, 13 May.

Albrecht, James, Lucas Navarro and Susan Vroman. 2009. "The Effects of Labour Market Policies in an Economy with an Informal Sector.” The Economic Journal 119, no. 539: 1105-1129.

Anjaria, Jonathan Shapiro. 2006. "Street Hawkers and Public Space in Mumbai." Economic and Political Weekly 41, no. 21: 2140-2146.

Awasthi, Rajul. 2012. "How Effective is the Tax Incentives Regime in Uganda." The Observer, 3 July.

Bacchetta, Marc, Ekkehard Ernst and Juana P. Bustamante. 2009. "Globalization and Informal Jobs in Developing Countries." International Labour Organization and World Trade Organization.

Bigsten, Arne and Steve Kayizzi-Mugerwa. 2001. "Is Uganda an Emerging Economy? A Report for the OECD Project "Emerging Africa"." Nordiska Afrikaintitutet, Research Report No. 118, Uppsala.

Bromley, Ray. 1990. "A New Path to Development? The Significance and Impact of Hernando De Soto's Ideas on Underdevelopment, Production, and Reproduction." Economic Geography 66, no. 4: 328-348.

Business Licensing Reform Committee. 2012. "Report on Uganda's Business Licensing Reforms." Volume I (March).

Busuulwa, Bernard. 2015. "Informal Sector Next Target in Uganda Tax Drive." The East African, 20 June.

Carbone, Giovanni. 2008. No-Party Democracy? Ugandan Politics in Comparative Perspective. Boulder: Lynne Rienner Publishers.

Carr, Marilyn and Martha Alter Chen. 2001. "Globalization and the Informal Economy: How Global Trade and Investment Impact on the Working Poor." Women in Informal Employment Globalizing and Organizing (May).

Collier, Paul and Ritva Reinikka. 2001. "Reconstruction and Liberalization: An Overview." In Ritva Reinikka and Paul Collier eds., Uganda's Recovery: The Role of Farms, Firms and Government, Washington D.C.: The World Bank, 15-47.

Cross, John C. 1998. Informal Politics: Street Vendors and the State in Mexico City. Stanford: Stanford University Press. 
De Soto, Hernando. 1989. The Other Path: The Invisible Revolution in the Third World. Translated by June Abbott. New York: Harper \& Row.

Djankov, Simeone et al. 2010. "The Effect of Corporate Taxes on Investment and Entrepreneurship." American Economic Journal: Macroeconomics 2, no. 3: 31-64.

Fjeldstad, Odd-Helge. 2005. "Corruption in Tax Administration: Lessons from Institutional Reforms in Uganda." Chr. Michelsen Institute, Working Paper 2005: 10.

Fox, Louise and Obert Pimhidzai. 2011. "Is Informality Welfare-Enhancing Structural Transformation? Evidence from Uganda." The World Bank, Policy Research Working Paper 5866 (October).

Gauthier, Bernard and Jonathan Goyette. 2014. "Taxation and Corruption: Theory and Firm-Level Evidence from Uganda.” Applied Economics 46, no. 23: 2755-2765.

Gërxhani, Klarita. 2004. "The Informal Sector in Developed and Less Developed Countries: A Literature Survey." Public Choice 120, no. 3/4: 267-300.

Ghosh, Amit and Saumik Paul. 2008. "Opening the Pandora's Box? Trade Openness and Informal Sector Growth.” Applied Economics 40, no. 15: 1995-2007.

Goodfellow, Tom. 2012. "State Effectiveness and the Politics of Urban Development in East Africa: A Puzzle of Two Cities, 2000-2010." PhD Dissertation, The London School of Economics and Political Science.

Gyimah-Brempong, Kwabena. 2002. "Corruption, Economic Growth, and Income Inequality in Africa." Economics of Governance 3, no. 3: 183-209.

Habib-Mintz, Nazia. 2009. "To What Extent can the Informal Economy Concept Adequately Explain the Dynamism of the Non-Formal Sector in Developing Countries." Journal of International Business and Economy 10, no. 1: 1-19.

Hart, Keith. 1973. "Informal Income Opportunities and Urban Employment in Ghana." The Journal of Modern African Studies 11, no. 1: 61-89.

Holland, Alisha C. 2016. "Forbearance." American Political Science Review 110, no. 2: 232-246.

Holland, Alisha C. 2017. Forbearance as Redistribution: The Politics of Informal Welfare in Latin America. Cambridge: Cambridge University Press.

Ihrig, Jane and Karine S. Moe. 2004. "Lurking in the Shadows: The Informal Sector and Government Policy." Journal of Development Economics 73, no. 2: 541-557.

International Labour Organization. 1972. "Employment, Incomes and Equality: A Strategy for Increasing Productive Employment in Kenya." International Labour Office, Geneva. 
Joshi, Anuradha, Wilson Prichard and Christopher Heady. 2012. "Taxing the Informal Economy: Challenges, Possibilities and Remaining Questions." International Centre for Tax and Development, Working Paper 4, (August).

Kasfir, Nelson. 1983. "State, Magendo, and Class Formation in Uganda." The Journal of Commonwealth \& Comparative Politics 21, no. 3: 84-103.

Ladu, Ismail Musa. 2015a. "How To Widen Tax Base to Gain Additional Revenue in Next Budget." Daily Monitor, 2 June.

Ladu, Ismail Musa. 2015b. "Shs 1.5 Trillion Lost Annually in Tax Exemptions." Daily Monitor, 21 December.

Lee, Eddy and Marco Vivarelli. 2006. "The Social Impact of Globalization in the Developing Countries.” International Labour Review 145, no. 3: 167-184.

Loayza, Norman V. 1996. "The Economics of the Informal Sector: A Simple Model and Some Empirical Evidence from Latin America." Carnegie-Rochester Conference Series on Public Policy, Volume 45, 129-162.

Losby, Jan L., Elaine L. Edgcomb, John F. Else, Erika T. Malm, Marcia E. Kingslow and Vivian Kao. 2002. "Informal Economy Literature Review." ISED Consulting and Research and The Aspen Institute (December).

Makara, Sabiti. 2009. "Decentralisation and Urban Governance in Uganda." PhD Dissertation, University of Witwatersrand.

Maloney, William F. 2004. “Informality Revisited.” World Development 32, no. 7: 1159-1178.

Mbanga, Jeff. 2003. "Tax Incentives Must End Now - IMF Boss.” The Observer, 10 December.

Mo, Pak Hung. 2001. “Corruption and Economic Growth.” Journal of Economic Growth 29, no. 1: 66-79.

Morange, Marianne. 2015. "Street Trade, Neoliberalisation and the Control of Space: Nairobi's Central Business District in the Era of Entrepreneurial Urbanism." Journal of Eastern African Studies 9, no. 2: 247-269.

Moser, Caroline O.N. 1978. "Informal Sector or Petty Commodity Production: Dualism or Dependence in Urban Development?" World Development 6, no. 9/10: 1041-1064.

Mweisgwa, Alon. 2012. "Experts Warn Against Tax Incentives." The Observer, 3 April.

Mwenda, Andrew M. and Roger Tangri. 2005. "Patronage Politics, Donor Reforms, and Regime Consolidation in Uganda." African Affairs 104, no. 416: 449-467. 
Nantaba, Agnes E. 2015. "Informal Business Taxes Start to Bite.” The Independent, 24 August.

Neuwirth, Robert. 2011. Stealth of Nations: The Global Rise of the Informal Economy. New York: Pantheon Books.

Nkonge, Alan G. 2013. "Ugandans Evade Taxes because of Corruption and Ignorance." Daily Monitor, 28 June.

Okidi, John A., Sarah Ssewanyana, Lawrence Bategeka and Fred Muhumuza. 2005. "Distributional and Poverty Impacts of Uganda's Growth: 1992-2003." Economic Policy Research Centre, Research Series No. 46, Kampala, Uganda (December).

Omolo-Okalebo, Fredrick, Tigran Haas, Inga Britt Werner and Hannington Sengendo. 2010. "Planning of Kampala City 1903-1962: The Planning Ideas, Values and their Physical Expression." Journal of Planning History 9, no. 3: 151-169.

Perry, Guillermo E. et al. 2007. Informality: Exit and Exclusion. The World Bank, Washington D.C.

Portes, Alejandro, Manuel Castells and Lauren A. Benton eds. 1989. The Informal Economy: Studies in Advanced and Less Developed Countries. Baltimore: Johns Hopkins University Press.

Portes, Alejandro and Saskia Sassen-Koob. 1987. "Making it Underground: Comparative Material on the Informal Sector in Western Market Economies." American Journal of Sociology 93, no. 1 : 30-61.

Portes, Alejandro and Richard Schauffler. 1993. "Competing Perspectives on the Latin American Informal Sector.” Population and Development Review 19, no. 1: 33-60.

Rakowski, Cathy A. 1994. "Convergence and Divergence in the Informal Sector Debate: A Focus on Latin America, 1984-92." World Development 22, no. 4: 501-516.

Schneider, Friedrich and Dominik H. Enste. 2000. "Shadow Economies: Size, Causes, and Consequences." Journal of Economic Literature 38, no. 1: 77-114.

Sparks, Donald L. and Stephen T. Barnett. 2010. "The Informal Sector in Sub-Saharan Africa: Out of the Shadows to Foster Sustainable Employment and Equity?" International Business \& Economics Research Journal 9, no. 5: 1-12.

Tangri, Roger and Andrew Mwenda. 2001. "Corruption and Cronyism in Uganda's Privatization in the 1990s." African Affairs 100, no. 398: 117-133.

Tax Justice Network - Africa. 2012. “Africa Tax Spotlight.” Newsletter, Second Quarter, Volume 2. 
Tax Justice Network - Africa and ActionAid International. 2012. "Tax Competition in East Africa: A Race to the Bottom? Tax Incentives and Revenue Losses in Uganda." (April).

Tentena, Paul. 2015. "Uganda Goes After Informal Sector.” East African Business Week, 14 June.

The World Bank. 2015a. "Global Economic Prospects: Having the Fiscal Space and Using It." Washington D.C. (January).

The World Bank. 2018a. "Doing Business 2019: Training for Reform - Uganda ." The World Bank Group, Washington D.C.

The World Bank. 2018b. "Financing for Growth and Development: Options for Raising More Domestic Revenues." Uganda Economic Update, Eleventh Edition, The World Bank Group (May).

The World Bank. 2012. "Poverty Trends in Uganda: Who Gained and Who Was Left Behind?" Inclusive Growth Policy Note 1 (June).

The World Bank. 2013. "Special Focus: Jobs: Key to Prosperity." Uganda Economic Update, Second Edition (August).

The World Bank. 2007. "Uganda: Moving Beyond Recovery: Investment \& Behaviour Change, for Growth." Country Economic Memorandum, Volume II: Overview, Report No. 39221UG (October).

The World Bank. 2015b. "The Growth Challenge: Can Ugandan Cities Get to Work?" Uganda Economic Update, Fifth Edition, The World Bank Group (February).

The World Bank. 2018c. "World Development Indicators: Uganda." Available online at: https://databank.worldbank.org/data/reports.aspx? source=2\& country=UGA.

Transparency International. 2018. "Corruption Perceptions Index 2017.”

Tripp, Aili Mari. 2010. Museveni's Uganda: Paradoxes of Power in a Hybrid Regime. Boulder: Lynne Rienner Publishers.

Uganda Bureau of Statistics. 2017. "2017 Statistical Abstract."

Uganda Bureau of Statistics. 2018. "Uganda National Household Survey 2016/17."

Uganda National Chamber of Commerce and Industry. 2015. "Tax Changes as per 2015/16 National Budget." (June 15). Available online at: http://www.chamberuganda.com/news/tax-changes-as-per-201516-national-budget/. 
United Nations. 2015. "World Urbanization Prospects: The 2014 Revision." Department of Economic and Social Affairs, New York.

United Nations. 2018. "World Urbanization Prospects: The 2018 Revision." Department of Economic and Social Affairs, New York. Data available online at: https://population.un.org/wup/.

Verick, Sher. 2006. "The Impact of Globalization on the Informal Sector in Africa." United Nations Economic Commission for Africa and Institute for the Study of Labor.

Young, Graeme. 2018. "De-Democratisation and the Rights of Street Vendors in Kampala, Uganda.” The International Journal of Human Rights 22, no. 8: 1007-1029.

Young, Graeme. 2017. "From Protection to Repression: The Politics of Street Vending in Kampala." Journal of Eastern African Studies 11, no. 4: 714-733.

Yusuff, Olabisi Sherifat. 2011. "A Theoretical Analysis of the Concept of Informal Economy and Informality in Developing Countries.” European Journal of Social Sciences 20, no. 4: 624636. 